\title{
A Obrigação Alimentária no Direito Brasileiro e os Direitos Humanos: Uma (Re)Leitura à Luz dos Tratados Internacionais
}

Helder Baruffi

Doutor. Professor da Faculdade de Direito e Relações Internacionais da UFGD (Universidade Federal da Grande Dourados). helderbaruffi@gmail.com

\section{Ana Cristina Baruffi}

Professora mestre da Universidade Regional de Blumenau

- Furb. anacrisbaruffi@gmail.com

\section{Resumo}

A dívida alimentar é, no direito brasileiro, o débito obrigacional que permite, como medida executiva, a prisão civil. Diante desta autorização constitucional, comungada com a integração do Pacto de São José da Costa Rica ao ordenamento jurídico brasileiro, o presente artigo tem como objetivo analisar a aplicação da medida executiva prisão civil no direito brasileiro num contraste com o direito internacional e direitos humanos, analisando os respectivos mandamentos jurídicos e a prática jurídica. Como principal objetivo, busca verificar se a forma como este meio executivo é aplicado no ordenamento jurídico brasileiro coincide com o proposto pela Convenção Americana de Direitos Humanos.

Palavras-chave: Obrigação alimentar. Prisão civil. Constituição. Tratados internacionais. 


\title{
PARENTAL SUPPORT AT BRAZILIAN'S LAW AND THE HUMAN RIGHTS: (RE)READ BASED ON THE INTERNATIONAL TREATIES
}

\begin{abstract}
The parental supoprt's debits the only debt output executable that allows to measure the executive civil prison. Given this constitutional authorization, added with the integration of the Pact of San José of Costa Rica to the Brazilian legal system, this article aims to analyze the application of the measure executive civilian prison in Brazilian law in contrast with international law and human rights, analyzing their legal commandments and legal practice. As the main goal, aims to verify if this is the way through executive is applied in the Brazilian legal coincides with that proposed by the American Convention on Human Rights.
\end{abstract}

Keywords: Maintenance. Civil prison. Constitution. International treaties.

\section{Sumário}

1 Introdução. 20 dever de prestar alimentos no direito de família brasileiro. 3 Consequências do não cumprimento da obrigação alimentar: medidas executivas. 4 Direito à liberdade pessoal na convenção americana de direitos humanos. 5 Consequências práticas da medida executiva prisão civil. 6 Considerações finais. 7 Referências 


\section{INTRODUÇÃO}

A Constituição da República Federativa do Brasil de 1988, de forma expressa, estabeleceu como objetivos fundamentais construir uma sociedade livre, justa e solidária e promover o bem de todos, sem preconceitos de origem, raça, sexo, cor, idade e quaisquer outras formas de discriminação (artigo $3^{\circ}$, Incisos I a IV), e, na sequência, estabeleceu que as relações internacionais devem ser regidas pelo princípio da prevalência dos direitos humanos (artigo $4^{\circ}$, Inciso II).

Dentre os direitos e deveres individuais e coletivos, estabeleceu que “Todos são iguais perante a Lei, sem distinção de qualquer natureza [...] garantindo-se a inviolabilidade do direito à vida, à liberdade, à igualdade, à segurança [...] (artigo $\left.5^{\circ}\right)$.

Observa-se que a Constituição Federal, à luz do princípio da dignidade da pessoa humana. estabeleceu um rol de princípios que visam a resguardar a liberdade de cada cidadão, permitir o pleno desenvolvimento, promover ações que objetivem à concretização destes princípios.

Na esteira deste pensamento, o país tem se envolvido, em âmbito internacional, na construção de um regramento principiológico, aderindo aos tratados internacionais, em especial àqueles que buscam a concretização e defesa dos Direitos Humanos, com reflexos no sistema normativo interno. ${ }^{1}$

É certo que as relações internacionais cada vez mais se intensificam. Os Estados deixaram de ser os únicos atores do cenário internacional e passaram a compartilhar, a partir da adesão a tratados internacionais, de um pensamento igualitário e fundado nos Direitos Humanos. É o Estado o principal irradiador das normas internacionais.

${ }^{1}$ Neste sentido, Monteiro, Marco Antonio Corrêa. Tratados internacionais de Direitos Humanos e Direito Interno. São Paulo: Saraiva, 2011. 
Como ressalta Valério de Oliveira Mazzuoli, ${ }^{2}$ um dos fatos mais marcantes do final do século 20 foi a expansão dos Direitos Humanos na agenda internacional, seja ela dos Estados e seus respectivos Ministérios de Relações Exteriores, seja das organizações internacionais de caráter global ou regional. E acrescenta: "Os direitos humanos tornaram-se, para falar como Erik Jayme, o novo leitmotiv a conduzir a cultura jurídica contemporânea”, ${ }^{3}$ ou seja, a meta a ser alcançada pela sociedade internacional em seu conjunto.

Neste sentido, tema relevante é a incorporação dos tratados internacionais de direitos humanos ao direito brasileiro, bem como sua posição hierárquica no plano das fontes normativas, em especial com a inserção, com a Emenda Constitucional $n^{\circ} 45$, de 2004, do $\S 3^{\circ}$ ao artigo $5^{\circ}$ da Constituição de 1988 que prescreve: “Os tratados e convenções internacionais sobre direitos humanos que forem aprovados, em cada Casa do Congresso Nacional, em dois turnos, por três quintos dos votos dos respectivos membros, serão equivalentes às emendas constitucionais”.

A análise dessas relações internacionais deve passar, necessariamente, pela força normativa da incorporação dos tratados internacionais de direitos humanos no ordenamento interno, como irradiador de ações concretas de promoção da dignidade humana. Como destaca Luciana B. Scotti " Los derechos fundamentales dan contenido, al menos en el mundo Occidental, al orden público internacional, al operar como límites a la aplicación de un derecho extranjero que los avasalle.”

${ }^{2}$ Mazzuoli, Valerio de Oliveira. Tratados Internacionais de Direitos Humanos e Direito Interno. São Paulo: Saraiva, 2010. p. 19.

${ }^{3}$ Idem.

${ }^{4}$ Scotti, Luciana B. El reconocimiento extraterritorial de la "maternidad subrogada": una realidad colmada de interrogantes sin respuestas jurídicas. Revista Pensar en Derecho, Buenos Aires, UBA, n. 1, p. 271, 2012. 
Nesta nova ordem internacional, os direitos das pessoas não têm mais apenas o texto constitucional como única base de sustentação, mas contam, também, com o braço internacional dos Direitos Humanos, o que exige o diálogo que devem ter o sistema internacional e o direito interno, quando se trata de proteger e assegurar direitos. A prática se dá no interior dos Estados que ratificam seus instrumentos de proteção. ${ }^{5}$

O tema Direitos Humanos está presente em quase todos os aspectos da vida pública. Isso porque as diversas questões ligadas ao assunto transitam em várias áreas do conhecimento e nomeiam e protegem valores - e comportamentos - sem os quais mulheres e homens não poderiam viver de maneira digna. São universais, indivisíveis e interdependentes. Universais: porque atribuídos igualmente a todas as pessoas, sem distinção, em todo o planeta. Indivisíveis e interdependentes: porque somente sua efetivação integral e completa garante que o princípio do respeito à dignidade da pessoa humana seja realizado. Os direitos econômicos e sociais não podem ser protegidos com prejuízo dos direitos civis e políticos concernentes à liberdade.

$\mathrm{Na}$ esfera internacional, os principais documentos existentes para a promoção e defesa dos Direitos Humanos são a Declaração Universal dos Direitos Humanos, o Pacto dos Direitos Civis e Políticos e seus protocolos adicionais, o Pacto dos Direitos Econômicos, Sociais e Culturais, e a Convenção Americana dos Direitos Humanos, além de pelo menos 13 convenções ou declarações da Organização das Nações Unidas (ONU) que focalizam temas específicos como o racismo, direitos da mulher, criança, trabalhadores migrantes, tortura, desaparecimentos forçados, povos indígenas e pessoas com deficiência. ${ }^{6}$

\footnotetext{
${ }^{5}$ Mazzuoli, Valerio de Oliveira. Op. cit., p. 20.

${ }^{6}$ Cf. <http://www.sdh.gov.br>.
} 
No Brasil, a Constituição Federal de 1988 incorporou os direitos consignados na Declaração Universal e demais tratados internacionais de proteção aos direitos humanos, assegurando a todos que eles sejam garantidos pelo Estado com o apoio de toda a sociedade, estando a cargo da Secretaria de Direitos Humanos da Presidência da República (SDH/ PR) a articulação interministerial e intersetorial das políticas de promoção e proteção aos Direitos Humanos no Brasil. ${ }^{7}$ Criada em 1977 dentro do Ministério da Justiça, foi alçada ao status de Ministério em 2003.

Dentre as atribuições da SDH/PR, está a de coordenar a Política Nacional de Direitos Humanos segundo as diretrizes do Programa Nacional de Direitos Humanos.

Assim como a Secretaria de Direitos Humanos age no interior do Estado para promover o acesso igualitário aos direitos, também a família é o espaço de construção da cidadania e defesa dos Direitos Humanos. É o lócus privilegiado de realização dos direitos humanos na medida em que se constitui a primeira socialização. ${ }^{8}$

Com Paulo Lobo, entretanto, a aplicabilidade dos direitos fundamentais nas relações meramente privadas desafia a argúcia dos juristas, pois, na maioria dos casos, provoca a colisão dos direitos fundamentais das pessoas em conflito, ${ }^{9} \mathrm{v} . \mathrm{g}$, o direito à vida (alimentos) e à liberdade.

De outra forma, rupturas conjugais implicam dever de cuidado, responsabilidade, normalmente expresso no dever de alimentos, tema que deve ser lido à luz da construção teórico-normativa internacional de defesa dos direitos humanos. Este olhar é o que se pretende com este trabalho

${ }^{7}$ Cf. <http://www.sedh.gov.br/>. Acesso em: 10 mar. 2013.

${ }^{8}$ Berger, P.; Luckman, T. A construção social da realidade.

${ }^{9}$ Lobo, Paulo. Direito de família e colisão de direitos fundamentais. Revista dos Tribunais, ano 101, v. 920, jun. 2012. 
que tem por objeto mediato o dever de prestar alimentos e, como objeto próximo, a dívida decorrente do não cumprimento do dever de cuidado e a possibilidade de prisão civil do devedor de alimentos.

Evidente a colisão de princípio e sua (re)leitura.

\section{O DEVER DE PRESTAR ALIMENTOS NO DIREITO DE FAMÍLIA BRASILEIRO}

A Constituição Brasileira de 1988, no artigo 227, define que é dever da família, juntamente com o Estado e a sociedade,

[...] assegurar à criança, ao adolescente e ao jovem, com absoluta prioridade, o direito à vida, à saúde, à alimentação, à educação, ao lazer, à profissionalização, à cultura, à dignidade, ao respeito, à liberdade e a convivência familiar e comunitária, além de colocá-los a salvo de toda forma de negligência, discriminação, exploração, violência, crueldade e opressão.

O princípio constitucional expressa, de forma inequívoca, o caráter geral dos direitos humanos expresso na Declaração Universal e demais documentos internacionais relativos à proteção da pessoa humana. Como se observa, o dispositivo constitucional define que é dever, de forma cooperada entre a família, o Estado e a sociedade, assegurar à criança, ao adolescente e ao jovem uma série de direitos que dizem da dignidade da pessoa humana, relativas à própria pessoa (direito à vida, à saúde, à alimentação), relativas à própria pessoa, mas em estreita interação com o outro (direito à educação, ao lazer, à cultura) e relativas à pessoa em sociedade (direito à profissionalização, à liberdade, à convivência familiar e comunitária). Por fim, reafirma os princípios gerais expressos na Declaração Universal ao propugnar por colocá-los a salvo de toda forma de negligência, discriminação, exploração, violência, crueldade e opressão. Não é demais ressaltar que a Constituição brasileira, ao ser promulgada 
em 1988, foi nominada Constituição Cidadã. ${ }^{10}$ Também é certo que a Constituição de 1988 reflete, em boa parte, o próprio espírito do povo brasileiro ao destacar e repetir, em minúcias, os direitos, como reiteradamente tem asseverado Luis Alberto David Araújo, em suas palestras, quando trata da Proteção constitucional das pessoas com deficiência. ${ }^{11}$ Esse o sentido do artigo $5^{\circ}$, que possui 78 incisos. $^{12}$

A obrigação alimentar - princípio constitucional e ação que decorre dos liames familiares biológicos ou socioafetivos - além dos outros direitos previstos no artigo 277 da Constituição do Brasil, é um instituto complexo, com reclamo de permanente atualização para sua aplicação. ${ }^{13}$

O ser humano é ser carente, ser em projeto. Assim reflete Roberto Andorno, ${ }^{14}$ com assento em Kant:

${ }^{10} \mathrm{Cf}$. Discurso do então presidente da Assembleia Nacional Constituinte, deputado Ulisses Guimarães. "A Constituição é caracteristicamente o estatuto do homem. É sua marca de fábrica. $\mathrm{O}$ inimigo mortal do homem é a miséria. O estado de direito, consectário da igualdade, não pode conviver com estado de miséria. Mais miserável do que os miseráveis é a sociedade que não acaba com a miséria. Tipograficamente é hierarquizada a precedência e a preeminência do homem, colocando-o no umbral da Constituição e catalogando-lhe o número não superado, só no art. $5^{\circ}$, de 77 incisos e 104 dispositivos. Não lhe bastou, porém, defendê-lo contra os abusos originários do Estado e de outras procedências. Introduziu o homem no Estado, fazendo-o credor de direitos e serviços, cobráveis inclusive com o mandado de injunção. Tem substância popular e cristã o título que a consagra: 'A Constituição cidadã”. Disponível em: <http://www.senado.gov.br/noticias/.../Encarte_constituição_20_anos.pdf . Acesso em: 10 mar. 2013.

${ }^{11}$ A obra de referência é encontra para free download no site do próprio autor em <http:// www.pessoacomdeficiencia.gov.br/app/sites/default/files/publicacoes/a-protecao-constitucional-das-pessoas-com-deficiencia_0.pdfs.

${ }^{12}$ Originariamente 77 incisos e 104 dispositivos. O inciso 78 foi incluído pela Emenda Constitucional $\mathrm{n}^{\circ}$ 45, de 2004. "LXXVIII a todos, no âmbito judicial e administrativo, são assegurados a razoável duração do processo e os meios que garantam a celeridade de sua tramitação".

${ }^{13}$ Cf. Cahali, Yussef Said. Dos alimentos. 6. ed. São Paulo: Revista dos Tribunais, 2009.

${ }^{14}$ Andorno, Roberto. Bioética y dignidad de la persona. 2. ed. Madrid: Tecnos, 2012. p. 72. 
La persona merece ser siempre tratada como un fin en sí y nunca como un simple medio para satisfacer intereses ajenos. La dignidad de la persona es "algo que se ubica por encima de todo precio y, por lo tanto, no admite nada equivalente"; mientras las cosas tienen "precio", las personas tienen "dignidad".

En otras palabras, la dignidad, como prerrogativa característica de las personas, es un valor absoluto que escapa a todo cálculo utilitarista de costos-beneficios.

Andorno destaca que a compreensão de dignidade implica dois sentidos distintos: a dignidade intrínseca, que se refere ao valor que possui todo ser humano "en virtud de su mera condición humana, sin que ninguna cualidad adicional sea exigible. Se trata de un valor que está indisolublemente ligado al propio ser de la persona y por ello es el mismo para todos y no admite grados” e a dignidade ética que faz referência, não à pessoa, "sino a su obrar. En tal sentido, el ser humano se hace él mismo mayormente digno cuando su conducta está dirigida a la realización del bien”. ${ }^{15}$ É esta dignidade que se tem de proteger.

O ser humano, por natureza, é carente desde a sua concepção; em sua trajetória histórica e temporal, ou seja, em seu viver ou estar no mundo, "a sua dependência dos alimentos é uma constante, posta como condição de vida”. Daí a expressividade da palavra "alimentos” no seu significado vulgar: tudo aquilo que é necessário à conservação do ser humano com vida. ${ }^{16}$

\footnotetext{
${ }^{15}$ Ibidem, p. 73.

${ }^{16}$ Cahali, Yussef Said. Op. cit., p. 15.
} 
Conforme destaca Maria Berenice Dias, ${ }^{17}$ para o direito "alimento não significa somente o que assegura a vida. A obrigação de alimentar tem um fim precípuo: atender às necessidades de uma pessoa que não pode prover com sua própria subsistência”. Em leitura aos dispositivos do código civil observa-se que não há uma definição do que sejam alimentos. Sua leitura decorre do preceito constitucional que assegura à criança $\mathrm{e}$ ao adolescente o direito à vida, à saúde, à alimentação, à educação, ao lazer, à profissionalização, à cultura, à dignidade, ao respeito, à liberdade e à convivência familiar e comunitária (CF 227). E afirma ainda a autora citada: "Quem sabe aí se possa encontrar o parâmetro para a mensuração da obrigação alimentar. Talvez o seu conteúdo possa ser buscado no que entende a lei por legado de alimentos (CC1920): sustento, cura, vestuário, e casa, além de educação, se o legatário for menor.”18

Na concepção de Pontes de Miranda, no que respeita ao direito à alimentação, em sentido amplo, abrangeria todo o necessário ao sustento, morada, vestuário, saúde e educação do ser humano,${ }^{19}$ não podendo deixar de incluir neste rol o lazer, que também é um item essencial para o desenvolvimento sadio do indivíduo. ${ }^{20}$

Orlando Gomes ${ }^{21}$ ressalta que a palavra “alimentos", adotada no Direito para designar o conteúdo de uma pretensão ou de uma obrigação, "vem a significar tudo o que é necessário para satisfazer os reclamos da

\footnotetext{
${ }^{17}$ Dias, Maria Berenice. Manual de Direito de Família. 8. ed. São Paulo: RT, 2012. p. 459. ${ }^{18}$ Ibidem, p. 459.

${ }^{19}$ Miranda, Francisco Cavalcanti Pontes de. Tratado de direito privado. 4. ed. São Paulo: RT, 1983. T. 9. $§ 1.000$, n. 1, p. 207.

${ }^{20}$ Assis, Araken de. Manual da execução. 11. ed. São Paulo: RT, 2007. p. 905-906.

${ }^{21}$ Gomes, Orlando. Direito de família. Rio de Janeiro: Forense, 1968. p. 323.
} 
vida”. Mais amplamente, "é a contribuição periódica assegurada a alguém, por um título de direito, para exigi-la de outrem, como necessário à sua manutenção". ${ }^{22}$

Na esteira da Constituição de 1988, o Código Civil Brasileiro de 2002, dentre os artigo 1.694 a 1.710, determina quem se torna responsável pela prestação destes alimentos que são voltados às necessidades básicas e vitais daqueles que não podem custear, de modo compatível com a sua condição social. Aos parentes próximos - biológicos ou socioafetivos compete a obrigação alimentar.

A partir da doutrina, ${ }^{23}$ o direito à prestação alimentícia apresenta as seguintes características: (a) é um direito pessoal, por ter escopo tutelar a integridade física do indivíduo; logo sua titularidade não passa a outrem; (b) é intransferível em relação ao credor, pois o crédito não pode ser cedido a outrem, por ser inseparável da pessoa do credor, isso quanto às parcelas vincendas, pois a legislação nada fala das parcelas vencidas, portanto nada obsta a sua cessão a outrem; (c) é irrenunciável. $\mathrm{O}$ direito pode deixar de ser exercido, mas não pode ser renunciado, principalmente quando derivados do parentesco. O encargo alimentar é de ordem pública; (d) é imprescritível. As prestações são prescritíveis (cf. artigo 206, $\S 2^{\circ}$, as prestações alimentícias prescrevem em dois anos), mas o direito aos alimentos é imprescritível; (e) é impenhorável. Destinados à sobrevivência, não podem ser penhorados, exceto os frutos; (f) é incompensável. Eventual compensação dos alimentos com outra obrigação anularia o caráter alimentar dos mesmos; (g) é intransacionável. O caráter personalíssimo do direito aos alimentos afasta a possibilidade de transação. No direito brasileiro, a transação é possível para os direi-

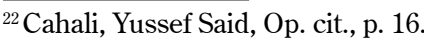

${ }^{23}$ Venosa, Sílvio de Salvo. Direito civil. Direito de família. 10. ed. São Paulo: Atlas, 2010; Cahali, Youssef Said. Dos alimentos. São Paulo: RT, 2009.
} 
tos patrimoniais de caráter privado (artigo 841). O direito a alimentos é direito privado, mas de caráter pessoal e com interesse público; (h) é atual, ou seja, visa a satisfazer necessidades atuais ou futuras; (i) é irrestituível. O pagamento dos alimentos é sempre bom e perfeito, ainda que recurso venha modificar decisão anterior, suprimindo-os ou reduzindo o seu montante; (j) é variável, pois, modificadas as situações econômicas e as necessidades das partes, deve ser alterado o montante da prestação, podendo ocorrer sua extinção (artigo 1699 CC); (l) é divisível entre os obrigados (artigos 1696 e 1697 CC).

Resumidamente, a obrigação de prestar alimentos tem as seguintes características: (a) condicionalidade - só surge a obrigação de alimentar se houver o preenchimento de todos os requisitos e pressupostos legais (previstos no Código Civil); (b) mutabilidade do quantum; (c) reciprocidade; (d) peridiocidade.

O dever de prestar alimentos possui tal importância que é regrado no Direito brasileiro não apenas por regras nacionais, mas pela adesão do Estado brasileiro a diversos instrumentos internacionais, destacando-se o Código de Bustamante - Havana, de 1928 - que define que a natureza jurídica da regra que dá direito a alimentos é de ordem pública internacional; a Convenção Interamericana sobre Obrigação de Prestar Alimentos Montevidéu - $1989^{24}$ que determina o dever de cooperação internacional quando credor e devedor alimentícios residirem em Estados diversos e, principalmente, a Convenção Americana de Direitos Humanos - também chamada de Pacto de São José da Costa Rica - que prevê uma penalidade gravosa ao devedor alimentício ao permitir, como única possibilidade de prisão civil, a decorrente de débito alimentar (artigo $7, \S 7^{\circ}$ ).

${ }^{24}$ Decreto Legislativo 1, de 28/2/96, Publicado em 29/2/96 
Daí a importância do diálogo das fontes proposto por Valério de Oliveira Mazzuoli, com fundamento em Erik Jayme. ${ }^{25}$ Conforme salienta Mazzuoli, os direitos humanos encontram proteção em diversos contextos (normas de proteção) e em diversos instrumentos (mecanismos de proteção). Os direitos humanos na pós-modernidade, portanto, têm proteção plural, sendo necessário, para sua aplicação, não a hierarquização de uma ou outra norma, interna ou externa, mas, sim, um verdadeiro diálogo, ao que propõe como "Controle de Convencionalidade" ${ }^{26}$

Tendo presentes os pressupostos - dignidade da pessoa humana, expresso nos diversos contextos e instrumentos de proteção externos e na Constituição Brasileira de 1988, e o dever de a família, o Estado e a sociedade assegurar à criança e ao adolescente o direito à alimentação, ou seja, o direito aos alimentos -, passa-se a enfrentar a questão central da investigação, qual seja, analisar a atualidade da medida executiva prisão civil por dívida de alimentos, uma das exceções ao princípio geral de liberdade, constante da parte final do Inciso LXVII do artigo $5^{\circ}$ da Constituição Federal do Brasil “- não haverá prisão civil por dívida, salvo a do responsável pelo inadimplemento voluntário e inescusável de obrigação alimentícia e a do depositário infiel ${ }^{27 ”}$ em acordo com a mesma exceção prevista no artigo $7^{\circ}$, item 7, parte final, da Convenção Americana sobre Direitos Humanos.

Articulo 7. Derecho a la Libertad Personal

25 "Mazzuoli, Valerio de Oliveira. Op. cit., p. 129 et seq.

${ }^{26}$ Ibidem, p. 207.

${ }^{27}$ A prisão civil por descumprimento à obrigação de depósito foi considerada inconstitucional pelo STF, restando tão somente o permissivo legal de prisão civil por dívida alimentária. 
7. Nadie será detenido por deudas. Este principio no limita los mandatos de autoridad judicial competente dictados por incumplimientos de deberes alimentarios. $^{7}$

Ressalte-se que a Constituição Federal não determina a prisão civil do devedor de alimentos. Ela é permissiva. Para além dessa única hipótese, decreto judicial de prisão civil por dívida é inconstitucional.

\section{CONSEQUÊNCIAS DO NÃO CUMPRIMENTO DA OBRIGAÇÃO ALIMENTAR: MEDIDAS EXECUTIVAS}

No âmbito do direito brasileiro, além da Constituição Federal, que valida outros textos normativos sobre a prisão civil do devedor de alimentos, existem a Lei de Alimentos (Lei n⿳ 5.478, de 25 de dezembro de 1968, artigo 19) e o Código de Processo Civil (Lei n⿳ํㅗ 5.869, de 11 de janeiro de 1973 , artigo $733, \S 1^{\circ}$ ).

A Lei de Alimentos, nos artigos 16 a 19, prevê uma série de atos especiais que devem ser cumpridos visando o pagamento da prestação devida até o decreto, excepcional da prisão do alimentante faltoso. A falta de pagamento das prestações alimentícias enseja a sua cobrança via procedimento de execução, na modalidade execução por quantia certa contra devedor solvente, previsto nos artigos 732 a 735 do Código de Processo Civil e artigos 16 a 19 da Lei n. 5.478/68 (Lei de Alimentos). São possíveis as seguintes medidas executivas para o adimplemento do crédito: desconto em folha, expropriação e coerção indireta, que culmina na possibilidade de prisão civil.

O título executivo pode decorrer tanto de sentenças, decisão interlocutória ou, ainda, sentença homologatória de acordo, bem como acordos de alimentos extrajudiciais. Para estes, também é possível o uso de todas as medidas executivas para o adimplemento do crédito. 


\section{Destacam Fredie Didier Junior et al. ${ }^{28}$ :}

É preciso observar tal ordem de preferência entre as medidas executivas da execução de alimentos. Com efeito, o art. 16 da referida Lei n. 5.478/1968 prioriza o uso do desconto em folha, com clara remissão ao art. 734 do CPC, o que se justifica em razão do alto grau de eficiência desse tipo de medida. Já o art. 17 prevê que, se não for possivel o desconto em folha, deve-se lançar mão da expropriação de aluguéis ou outros rendimentos do devedor (observando-se o art. 671 do CPC, pois se trata de crédito). Por fim, o art. 18 estipula a possibilidade de o credor, em último caso, requerer a execução na forma dos artigos 732, 733 e 735do CPC, isto é, por via de expropriação e/ou coerção pessoal, o que fica a seu critério.

\section{$[\ldots]$}

Daí dizer-se que, se não for possível o uso das duas primeiras vias (desconto ou expropriação de aluguéis/rendimentos), compulsória que são, cabe ao credor escolher entre a expropriação de outros bens ou coerção indireta.

\section{$[\ldots]$}

Contudo, o meio utilizado deve ser escolhido atentando-se para duas circunstâncias essenciais, a serem ponderadas no caso concreto: de um lado, sua idoneidade e aptidão para conferir uma tutela efetiva ao credor; de outro, a menor onerosidade para o devedor (CPC, art. 620).

Não apenas isso. Convém salientar que a prática judicial criou a regra de que o alimentante só pode sofrer a aplicação da medida executiva prisão civil quando deixar de pagar três prestações, seja antes da citação, seja as que vencerem durante o processo, conforme Súmula 309 do Superior Tribunal de Justiça.

${ }^{28}$ Didier Junior, Fredie et al. Curso de Direito Processual Civil. 4. ed. Salvador: Editora Juspodivm, 2012. p. 708-709. Vol. 5. 
No âmbito jurídico brasileiro, de acordo com pesquisa doutrinária e a prática jurídica, percebe-se que o réu “devedor” é tratado como se criminoso fosse, apesar de ter natureza civil a prisão prevista constitucionalmente. Seu objetivo não é a aplicação de uma sanção punitiva, mas tão somente a sujeição do devedor a um meio coercitivo que o leve a sanar o inadimplemento. Tal é verdade que a falta de pagamento das prestações alimentícias é considerada abandono material, tutelado no artigo 244 do Código Penal.

É possível visualizar a gravidade da medida no pensamento de Maria Berenice Dias, ${ }^{29}$

O alimentante só se livra da coerção pessoal mediante o pagamento das parcelas executadas e de todas as que se vencerem até a data do efetivo pagamento. Como se tratam de prestações periódicas, cabível invocar o disposto no art. 290 do estatuto processual: a condenação compreende as prestações vencidas no curso do processo. A falta de pagamento, ainda que não autorize novo decreto de prisão, também não enseja a propositura de novo procedimento executório, mas admite novo aprisionamento pelas parcelas impagas depois do cumprimento da pena.

O mesmo pensamento é compartilhado pelo Supremo Tribunal Federal. Entende o STF que a permissão da prisão civil do devedor de alimentos decorre da presunção de que a necessidade de sobrevivência do alimentando (direito à vida) prevalece sobre o direito à liberdade do devedor-alimentante. A estes dois direitos, elevados ao grau de princípios no Direito brasileiro, não se aplica mais a ponderação e razoabilidade, já restando definido que o direito à vida se sobrepõe ao direito à liberdade, posição que não se sustenta se adotarmos o princípio do diálogo das fontes.

${ }^{29}$ Dias, op. cit. p. 515 . 
Convém destacar que estes princípios são abraçados tanto por convenções que tratam de direitos humanos quanto, também, são considerados direitos fundamentais.

Norberto Bobbio ${ }^{30}$ afirma que "Os direitos do homem, por mais fundamentais que sejam, são direitos históricos, ou seja, nascidos em certas circunstâncias, caracterizados por lutas em defesa de novas liberdades contra velhos poderes, e nascidos de modo gradual, não todos de uma vez e nem de uma vez por todas.”

Pensamento compartilhado por Perez Luño, ${ }^{31}$ "Los derechos humanos aparecen como un conjunto de facultades e instituciones que, en cada momento histórico, concretan las exigencias de la dignidad, la libertad y la igualdad humana, las cuales deben ser reconocidas positivamente por los ordenamientos jurídicos a nivel nacional e internacional”.

Em que pese inerentes à condição humana da pessoa, o reconhecimento destes direitos é decorrente da evolução histórica na defesa da concretização da liberdade, igualdade e dignidade da pessoa humana, tanto em caráter individual quanto em caráter universal.

Estes direitos, quando reduzidos à norma dentro de um ordenamento jurídico, são definidos como fundamentais. Neste sentido, destaca José Joaquim Gomes Canotilho: ${ }^{32}$

As expressões direitos do homem e direitos fundamentais são freqüentemente utilizadas como sinônimas. Segundo a sua origem e significado poderíamos distingui-las da seguinte maneira: direitos do homem são direitos válidos para todos os povos e em todos os tempos; direitos

\footnotetext{
${ }^{30}$ Bobbio, Norberto. A era dos Direitos. 1. ed. 12. tir. Rio de Janeiro: Campus, 1992. p. 5

${ }^{31}$ Luño, Antonio Enrique Pérez Luño. Derechos Humanos, Estado de Derecho y Constitucion. 6. ed. Madrid: Tecnos, 1999. p. 48.

${ }^{32}$ Canotilho, José Joaquim Gomes. Direito Constitucional e Teoria da Constituição. 3. ed. Coimbra: Almedina, 1998. p. 259.
} 
fundamentais são os direitos do homem, jurídico-institucionalmente garantidos e limitados espacio-temporalmente. Os direitos do homem arrancariam da própria natureza humana e daí o seu caráter inviolável, intertemporal e universal; os direitos fundamentais seriam os direitos objetivamente vigentes numa ordem jurídica concreta.

É certo que a Constituição é o lugar no qual quase todos os princípios podem ser encontrados. Por força dessa virada metodológica que reconhece efetiva força jurídica aos princípios, os valores e princípios expressos na Constituição não se apresentam apenas como conselhos morais ou um catálogo de boas intenções. Ao contrário, "são normas jurídicas, intimamente ligadas à ideia de dignidade da pessoa humana e de limitação do poder, positivadas no plano constitucional de determinado Estado Democrático de Direito, que, por sua importância axiológica, fundamentam e legitimam todo o ordenamento jurídico.”33

Distinguem-se dos direitos do homem - valores ético-políticos ligados à dignidade da pessoa humana, não positivados, e dos direitos humanos - valores ligados à dignidade da pessoa humana que foram positivados na esfera internacional por meio de tratados.

No que diz respeito aos preceitos legais de direitos da família, não se pode negar a eles o enquadramento dentro dos direitos humanos. Isso porque,

Ao falar de direitos humanos, logo vem à mente o direito à vida. Mas não se pode pensar na vida humana sem pensar na família. $\mathrm{O}$ direito à vida implica e funda o direito à família como o primeiro na ordem jurídica das entidades familiares, o mais fundamental dos direitos familiais. Mas também outros direitos humanos levam a pensar na família. Liberdade, igualdade, fraternidade, felicidade, segurança, saúde, educação e outros valores humanos básicos se relacionam com o direito à família $\mathrm{e}$

${ }^{33}$ Marmelstein, George.Curso de direitos fundamentais. São Paulo: Atlas, 2009. p. 20 
remetem ao lar, onde eles se concretizam em direitos familiais. Mas, a partir do lar e a principiar do direito à família, os direitos familiais só se realizam plenamente se estiverem envolvidos e sustentados pelo afeto.

Da família, o lar é o teto, cuja base é o afeto. Lar sem afeto desmorona. Por isso, os direitos ao afeto e ao lar se associam entre si, bem como se ligam aos demais direitos operacionais da família, pelos quais devem ser assegurados em seus vários aspectos: o físico, o social, o econômico, o cultural e o psíquico.

$[\ldots]$

O discurso dos direitos humanos tem sido crivado de ideologia e demagogia. Não há sequer a preocupação de dizer o que são "direitos humanos”. Por isso, convém defini-los: são poderes-deveres de todos para com cada um e de cada um para com todos, visando realizar a essência humana em todas as existências humanas, concretizar o ser humano em todos os indivíduos humanos, segundo os padrões de dignidade do momento histórico.

Muitos desses poderes-deveres se exercem no seio da família. A família é o lar dos direitos humanos. Por isso, o direito fundamental à família $\mathrm{e}$ os seus direitos operacionais devem ser garantidos sem discriminação alguma, a fim de que o direito de família seja não só o mais humano dos direitos, como também o mais humano dos direitos humanos. ${ }^{34}$

Desta forma, os atos que não assegurem os direitos da família, seja em qual aspecto for, violam os direitos humanos. O direito à alimentação, como um direito à vida, assim como o direito à liberdade, constituem sim valores e merecem a ponderação. Como assinala Paulo Lôbo, ${ }^{35} \mathrm{com}$

\footnotetext{
${ }^{34}$ Barros, Sergio Resende de. Direitos Humanos da família: principiais e operacionais. Texto básico da palestra proferida em 3 de dezembro de 2003, no II Encontro de Direito de Família do IBDFAM/AM, realizado em Manaus, sob patrocínio da seccional do Amazonas do IBDFAM - Instituto Brasileiro de Direito de Família. Igualmente, da palestra ministrada no Curso de Direito de Família promovido pelo Instituto dos Advogados de São Paulo, em 25 de novembro de 2003. Disponível em: <http://www.srbarros.com.br/ pt/direitos-humanos-da-familia-principiais-e-operacionais.cont>. Acesso em: 2 mar. 2013.

${ }^{35}$ Lobo, Paulo. Op. cit., p. 107.
} 
estribo em Robert Alexy, em qualquer situação de colisão de direitos fundamentais entre os particulares, "o intérprete ou aplicador valer-se-á da ponderação entre os princípios concorrentes, definindo-se por aquele que, na situação concreta e ante as circunstâncias que a cercam, deve ter um peso maior, o que fundamentará a decisão, longe de qualquer escolha proveniente de prévio juízo de valor subjetivo”.

No atual contexto normativo, a prisão civil por dívida de alimentos merece uma (re)leitura por violar direitos humanos da família, representado no vínculo pai-filho. Embora a prisão civil seja, em muitas circunstâncias, a aparente única forma eficaz de obrigar o devedor a saldar sua dívida, é atitude que no tempo agride a integridade física e psicológica do devedor.

Certamente, a inteligência humana deve ser capaz de buscar fórmulas compensatórias mais próximas da obrigação descumprida e que não importem apenas somar um mal a outro, à efetividade do cumprimento do dever alimentar, com se apresenta na própria doutrina estrangeira.

\section{DIREITO À LIBERDADE PESSOAL NA CONVENÇÃO AMERICANA DE DIREITOS HUMANOS}

Historicamente, a prisão civil por dívida não é uma novidade na sociedade humana. Ela está presente nos mais diversos e importantes instrumentos jurídicos de cada época (Código de Hamurabi, Código de Manu, Lei de Dracon, Lei das XXII Tábuas, etc.), inclusive há registros na Bíblia, como na parábola do credor incompassivo (Mateus, 18: 23 a 35). Não deixou também de ser objeto de romances como Mercador de Veneza, de William Shakespeare.

Com a modernidade, as dívidas contraídas pelos cidadãos deixaram de ter reflexo punitivo sobre seu próprio corpo e começaram a priorizar a restituição pecuniária ao credor. 
$\mathrm{Na}$ forma de regular a matéria, pelo menos entre os países latinos do Continente Americano - diante da divisão bipolar em América do Norte e América Latina - sem muitas novidades e na mesma toada da Declaração das Nações Unidas sobre Direitos Humanos de 1948, da Convenção de Viena sobre tratados de 1969 e a Convenção Europeia dos Direitos Humanos de 1950, na Convenção Interamericana de Direitos Humanos de 1992 criou-se um Sistema Interamericano de Proteção aos Direitos Humanos, também conhecido como Pacto de São José da Costa Rica.

Da leitura do Pacto resta claro seu objetivo de proteger os Direitos Humanos com fundamento no princípio da dignidade da pessoa humana, e visa também a assegurar melhores condições a sociedade, firmando a ideia de Estado Democrático de Direitos, socialmente responsável, na busca de combater os males sociais e dar efetividade aos direitos que constam na Carta da Organização dos Estados Americanos.

O Brasil, como é sabido, é signatário do pacto.

A formalidade que recepcionou no ordenamento jurídico brasileiro a referida convenção, cumpridos os requisitos para admissão como lei ordinária, sendo aprovado por maioria simples no Congresso Nacional em apenas 1 (um) turno de votação em cada Casa Legislativa (Decreto Legislativo № 27), seguido de uma sanção expressa do Presidente da República (Decreto Executivo № 678), respeitando o disposto na CF, art.84, VIII. Importando observar que as normas definidoras dos direitos e garantias fundamentais têm aplicação imediata, segundo o $\S 1^{\circ}$ do Art. $5^{\circ}$ da $\mathrm{CF}^{36}$

\footnotetext{
${ }^{36}$ Linard, Daniel Gurgel. Alcantara, Michele Alencar da Cruz. A influência do Pacto de San José da Costa Rica no Instituto da Prisão Civil do Depositário Infiel no Brasil. In: ENCONTRO NACIONAL DO CONPEDI, 19., 2010, Fortaleza. Anais... Fortaleza, CE, 9, 10, 11 e 12 jun. 2010. Disponível em: <http://www.conpedi.org.br/manaus/arquivos/anais/fortaleza/3332.pdf>. Acesso em: 2 mar. 2013.
} 
Quanto à Convenção Americana sobre os Direitos Humanos Pacto de São José da Costa Rica - Luiz Flávio Gomes e Valério de Oliveira Mazzuoli ${ }^{37}$ tecem comentários gerais sobre esta, ressaltando o princípio básico de proteção à dignidade da pessoa humana.

Especialmente em relação ao artigo $7^{\circ}-$ Direito à Liberdade Pessoal e seus itens, ressaltam que a liberdade de que cuida este artigo é a física (pessoal), que consiste no direito de ir, vir e permanecer. É a liberdade de locomoção, protegida, no Brasil, quando cerceada ou violada, pelo remédio jurídico do habeas corpus.

Destacam, com fundamento no Informe Anual da Comissão Interamericana 1994, que "as palavras liberdade e segurança devem ser interpretadas conjuntamente e que se referem à liberdade física”. Para fins didáticos, explicitam que, no Brasil, a prisão pode ser penal ou extrapenal, esta subdividida em prisão civil e prisão administrativa. Anotam, como pacificado pela jurisprudência, ${ }^{38}$ que a prisão civil somente permanece vigente no ordenamento jurídico brasileiro quando fundada em obrigação alimentar.

Continuam a análise da Convenção realçando o princípio basilar da liberdade, também previsto na Constituição Federal de 1988 em seu artigo $5^{\circ}$, LXI, nestes termos: "Ninguém será preso, senão em flagrante delito ou por ordem escrita e fundamentada de autoridade judiciária competente, salvo nos casos de transgressão militar ou crime propriamente militar, definidos em lei”, remetendo a compreensão do texto constitucional ao disposto na Declaração Universal dos Direitos Humanos: “Ninguém será arbitrariamente preso, detido ou exilado” (DUDH, artigo IX), ao disposto

\footnotetext{
${ }^{37}$ Res. 1/95, caso 11.006, p. 101, Peru. Gomes, Luiz Flávio; Mazzuoli, Valerio de Oliveira. Comentários à Convenção Americana sobre Direitos Humanos. São Paulo: Revista dos Tribunais, 2009. p. 50.

${ }^{38}$ Supremo Tribunal Federal. HC 83.416-SP. Rel. Cezar Peluso, j. 14.10.2003.
} 
no Pacto Internacional dos Direitos Civil e Políticos: "Toda pessoa tem direito à liberdade e à segurança pessoais. Ninguém poderá ser preso ou encarcerado arbitrariamente. Ninguém poderá ser privado da sua liberdade, salvo pelos motivos previstos em lei e em conformidade com os procedimentos nela previstos” (artigo 9º 1 ) e na Convenção Americana sobre Direitos Humanos: "Ninguém pode ser privado de sua liberdade física, salvo pelas causas e nas condições previamente fixadas pelas Constituições políticas dos Estados-partes ou pelas leis de acordo com elas promulgadas” (artigo 7º, 3 ).

Observa-se que a regra geral é a da liberdade, um dos elementos nucleares da dignidade da pessoa humana, como decorre da análise dos demais itens do artigo $7^{0}$ da Convenção Americana sobre Direitos Humanos, que trazem forte conteúdo de proteção e garantias que deve cercar, quando necessária, a prisão de qualquer pessoa, sendo digno de nota a incorporação no direito interno brasileiro, as seguintes garantias: comunicação da prisão (artigo $5^{\circ}$, LXII), direito ao silêncio (artigo $5^{\circ}$, LXIII), direito de assistência (artigo 5ํㅜ LXIII), direito de identificação do responsável pela prisão (artigo $5^{\circ}$, LXIV). A privação de liberdade, isto é, a prisão, somente pode ocorrer em casos extremos, assim considerados pela lei. Não pode ser uma política de governo, nem mesmo uma política de coação em relação a obrigações patrimoniais. Com acerto o veto presidencial ao artigo 10 da Lei 12.318, de 26 de agosto de 2010 que trata da Alienação Parental. O referido artigo visava a incluir sanção de natureza penal ao genitor alienante, capaz de produzir maiores danos aos titulados do que aqueles que se buscava proteger. 
É certo que a transgressão dos direitos humanos, ranço do autoritarismo que ainda se faz presente no continente americano, origina uma sucessão de violações subsequentes. A partir da perda da liberdade, “os direitos à vida e à integridade pessoal ficam iminentemente ameaçados”. ${ }^{39}$

Por isto que, nos termos da Convenção Interamericana, a proteção à liberdade pessoal representa "tanto a proteção da liberdade física dos indivíduos como a segurança pessoal, em um contexto em que a ausência de garantias pode resultar na subversão da regra de direito e na privação dos detidos às formas mínimas de proteção legal”. ${ }^{40}$

Pela extensão do sentido de proteção legal à pessoa e à integridade física da pessoa humana, observa-se a superação do ranço tradicional de buscar solucionar problemas sociais pela ameaça da prisão.

\section{CONSEQUÊNCIAS PRÁTICAS DA MEDIDA EXECUTIVA PRISÃO CIVIL}

É importante o estudo da matéria, pois se verifica que os processos alimentares que seguem o procedimento do 733 do CPC não deixam de ser uma forma de atingir o alimentante, pois é notório que a ausência de pagamento de três parcelas de natureza alimentar enseja a prisão do alimentante (Súmula 309, STJ).

Tem-se por suposto que este procedimento - pedido de prisão civil por dívida de alimentos - muitas vezes, é utilizado exclusivamente como um meio de vingança da ex-cônjuge ou ex-companheiro(a), caracterizando-se em ato de alienação parental, como disciplinado pela Lei 12.318/2010.

${ }^{39}$ Jayme, Fernando G. Direitos humanos e sua efetivação pela Corte Interamericana de Direitos Humanos. Belo Horizonte: Del Rey, 2005. p. 130.

${ }^{40}$ Corte Interamericana de Direitos Humanos. Caso Bámaca Velásquez. Sentença de 25.11.2000. São José da Costa Rica, 2001. p. 116. 
A prisão retira o alimentante do convívio da sua nova família, da sociedade, do trabalho, o que viola não apenas o direito de liberdade deste, mas também a própria gênese do direito de família que é a relação de parentesco entre o pai e o filho, ou da nova família. São provocadores de sofrimento nos filhos, que passam a ter direitos violentados, como o de conviver em família, a proteção de ambos os pais, o direito ao pleno desenvolvimento com identidade dos pais.

Esta dificuldade na separação destes papéis favorece a alienação parental, que, devido a sua importância, restou tipificada na Lei 12.318, de 26.08.2010, como segue:

Art. $2^{\circ}$ Considera-se ato de alienação parental a interferência na formação psicológica da criança ou do adolescente promovida ou induzida por um dos genitores, pelos avós ou pelos que tenham a criança ou adolescente sob a sua autoridade, guarda ou vigilância para que repudie genitor ou que cause prejuízo ao estabelecimento ou à manutenção de vínculos com este.

Parágrafo único. São formas exemplificativas de alienação parental, além dos atos assim declarados pelo juiz ou constatados por perícia, praticados diretamente ou com auxílio de terceiros:

III - dificultar contato de criança ou adolescente com genitor;

IV-dificultar o exercício do direito regulamentado de convivência familiar;

Em uma perspectiva conforme aos marcos das Convenções e Tratados Internacionais e dos direitos fundamentais, mas ainda permitindo esta, destacou a Ministra Nancy Andrigui no acórdão lavrado nos autos do HC n. 39902: “a prisão deve ser decretada, excepcionalmente, apenas como meio de coagir o devedor a adimplir o débito alimentar e não como mecanismo de punição pelo não pagamento", posição que merece ser 
superada por formas outras de atendimento ao princípio constitucional do direito à alimentação, conforme expresso no artigo 227 da Constituição Federal de 1988.

A prisão por débito alimentar não apenas dificulta o contato da criança ou adolescente com o genitor como também o exercício do direito regulamentado de convivência familiar. Não se pode negar que a prisão civil por débito alimentar não pode deixar de ser considerada uma forma de alienação parental, até porque, atualmente não é utilizada na leitura da sua permissão na Convenção Americana dos Direitos Humanos.

É possível ver a gravidade da forma em que está sendo utilizado este procedimento, como no julgado colacionado a seguir, em que o Tribunal de Justiça do Rio Grande do Sul manifestou ser cabível a decretação da prisão civil do alimentante por inadimplemento quando não demonstrado o pagamento integral, não aceitando inclusive a justificativa de falta de condições. Neste sentido:

[...] agravo de instrumento. execução de alimentos pelo rito do artigo 733 do cpc. justificativa desacolhida. prisão civil decretada. Na ação de execução de alimentos já vencidos, pelo rito do art. 733 do CPC, não é aceitável a justificativa do inadimplemento por falta de condições econômico-financeira para o adimplemento. Como não demonstrado o pagamento integral do débito, perfeitamente cabível a prisão civil. $E$ pacífico o entendimento jurisprudencial de que descabe questionar o binômio possibilidade/necessidade em sede de execução, pois o débito executado já existe, e os alimentos subsequientes devem ser objetos de ação revisional. Recurso desprovido. (Agravo de instrumento $\mathrm{n}^{\mathrm{o}}$ 70023099351, Sétima Câmara Cível, Tribunal de Justiça do RS, Relator: Ricardo Raupp Ruschel, Julgado em 23/4/2008) (grifo nosso). 
Em que pese a não obrigatoriedade, mas sim a permissividade da prisão civil, como ato excepcional, o vício autoritário e punitivo sobressai ao respeito à dignidade humana. Como destaca Pablo Stolze Gagliano:41 "E no atual estágio do moderno Direito de Família, em que vivemos mudança de paradigmas legais e standards jurídicos, comodamente assentados em nossa mentalidade judiciária ao longo dos anos, nada melhor do que evitarmos qualquer tipo de vício de postura jurisprudencial, a fim de que nos afinemos com os novos tempos".

É preciso avançar. É preciso "uma acentuada dose de humanidade" ${ }^{22}$ no trato das questões familiares. A eficácia da prisão no plano prático também é colocada em dúvida, pois o devedor pode cumprir a pena e continuar inadimplente, aumentando o abismo moral e afetivo nas relações familiares rompidas. Não se defende a tese da exoneração do devedor de sua responsabilidade, mas de visualizar mecanismos ou caminhos alternativos à efetividade do cumprimento do dever alimentar, resguardando o complexo balanço entre o direito à vida do alimentando e o direito à liberdade do alimentante. ${ }^{43}$

Dada a ineficácia dos resultados e o dano causado pelo cerceamento da liberdade, notadamente em cárcere, alternativas são buscadas de aplicação possível e resultados mais eficazes, tanto no temperamento do dispositivo constitucional, quanto, por exemplo, limitando a execução a número certo de parcelas em atraso, conforme Súmula 309 do STJ “O débito ali-

\footnotetext{
${ }^{41}$ Disponível em: <http://www.juspodivm.com.br/i/a/\%7BF443AAFD-11DB-47D1-8EBF-0F73AD69EEA2\%7D_026.pdf>. Acesso em: 6 mar. 2013.

${ }^{42}$ Madaleno, Rolf. Direito de família - aspectos polêmicos. 2. ed. Porto Alegre: Livraria do Advogado, 1999. p. 13.

${ }^{43}$ Neste sentido: Grisard Filho, Waldyr. O futuro da prisão civil do devedor de alimentos: caminhos e alternativas. Disponível em: <http://www.academia.edu/1435914/O_futuro_ da_prisao_civil_do_devedor_de_alimentos_caminhos_e_alternativas $>$. Acesso em: $11 \mathrm{mar}$. 2013.
} 
mentar que autoriza prisão civil do alimentante é o que compreende as três prestações anteriores ao ajuizamento da execução e as que vencerem no curso do processo."

Soluções mais radicais e em consonância com uma leitura mais conforme ao princípio da dignidade da pessoa humana já são visualizadas, como, por exemplo, a Lei 13.074 da Província de Buenos Aires que criassem o Registro de Devedores Alimentários Morosos, que tem por objetivo organizar uma lista na qual figurem "Todo obligado al pago de cuota alimentaria cuya obligación conste en sentencia firme o convenio debidamente homologado que incumpliera con el pago de três veces continuadas o cinco alternadas una vez intimado y si no hubiere podido demostrar su cumplimiento deberá ser inscripto inmediatamente por orden judicial y a solicitud de parte mediante oficio al Registro de Deudores Alimentarios Morosos (Articulo 3). Trata-se de sancionar a conduta morosa por meio de diversas restrições, que condicionam as atividades pessoais, comerciais e bancárias dos devedores recalcitrantes (Articulo 5).

$\mathrm{Na}$ esteira do reconhecimento da dignidade da pessoa humana, de forma integral, países criaram o Fundo de Garantia dos Alimentos Devidos a Menores, ${ }^{44}$ que assegura o pagamento das prestações de alimentos em substituição do pai/mãe faltoso(a), no caso de incumprimento desta obrigação; certamente um avanço qualitativo inovador na política social desenvolvida pelo Estado, ao mesmo tempo em que se dá cumprimento ao objetivo de reforço da proteção social devida a menores.

No caso de Portugal, este Fundo de Garantia dos Alimentos Devidos a Menores é gerido pelo Instituto de Gestão Financeira da Segurança Social, a quem cabe assegurar o pagamento das prestações de alimentos

\footnotetext{
${ }^{44}$ Portugal. Decreto-Lei n⿳ํㅡㄴ 164/99. DR nº 111/99 Série I-A de 1999-05-13, Ministérios da Justiça e do Trabalho e da Solidariedade. Regula a garantia de alimentos devidos a menores prevista na Lei n. 75/98, de 19 de novembro de 1998.
} 
em caso de incumprimento da obrigação pelo respectivo devedor, por intermédio dos centros regionais de segurança social da área de residência do alimentado, após ordem do tribunal competente e subsequente comunicação da entidade gestora, podendo estes assegurar, melhor que outro serviço, a rápida e eficaz satisfação da garantia de alimentos devidos ao menor. ${ }^{45}$

O sistema penal brasileiro, como o das democracias contemporâneas, avançou em matéria de direitos humanos ao reconhecer que a pena privativa de liberdade não é a única possível, podendo a lei adotar, entre outras, a perda de bens, a de multa, a de uma prestação social alternativa até a suspensão ou a interdição de direitos (CF, artigo $5^{\circ}$, inciso XLVI). O principal exemplo é a Lei n⿳0 9.099/95, dos Juizados Especiais, que em seu artigo $2^{\underline{0}}$ prevê, sempre que possível, a conciliação e a transação.

Decisões neste sentido já estão sendo prolatadas:

\begin{abstract}
ALIMENTOS - ATRASO NO PAGAMENTO - MULTA - ADMISSIBILIDADE.

É permitido, tal como ocorre com a cláusula penal, de caráter contratual, que o Estado-juiz estabeleça, como mecanismo de conscientização para a razoável execução do título judicial, a imposição de multa (astreinte), um fator de inegável utilidade para a persuasão do provedor de alimentos a cumprir no prazo, o dever de depositar prestação. Admissibilidade. Estipulação em percentual razoável (15\%). Não-provimento. (TJSP, Ac. 241.020-4/4 - 3 ${ }^{\mathrm{a}}$ CDPriv., rel. Des. Ênio Santarelli Zuliani. j.5.11.02, DOESP 16.12.02) (Revista..., 2003, p. 124-126).
\end{abstract}

${ }^{45} \mathrm{Cf}$. $<$ http://www4.seg-social.pt/fundo-de-garantia-de-alimentos-devidos-a-menores $>$. Acesso em: 11 mar. 2013. 
O que se observa é o avanço, lento, mas concreto e consistente, de respeito à dignidade da pessoa humana. A tendência criminalizadora do pensamento jurídico brasileiro dá espaços aos Direitos Humanos e, neste sentido, a concretização do ideal de justiça.

\section{CONSIDERAÇÕES FINAIS}

O pensamento jurídico brasileiro, ombreado às contribuições da doutrina internacional sobre Direitos Humanos, tem avançado na garantia de direitos, particularmente visando a dar concretude ao princípio constitucional da dignidade da pessoa humana.

Notícias de violação de direitos ainda ocupam vasto horário dos jornais nacionais, com verdadeiros descasos à pessoa humana. Em paralelo a essas violações, porém, um esforço importante de reconhecimento e de concretização de direitos tem sido despendido no sentido de atualizar a Carta Constitucional de 1988, não em um processo de mutação constitucional, mas dando sentido ao desejo expresso pelos Constituintes de 1988 na construção da Carta Cidadã. O principal desejo é o de um país justo e de respeito aos Direitos Humanos. Por isso o vasto rol de direitos fundamentais individuais e sociais expressos nos artigos $5^{\circ}$ (direitos individuais) e $6^{\circ}$ a 11 (direitos sociais).

O Direito à alimentação está objetivamente prescrito no artigo 227 da Constituição Federal, junto com outros direitos que dizem da dignidade da pessoa e visam a sua integral proteção. O legislador constituinte, em 1988, entretanto, não venceu o ranço histórico de penalização/criminalização das obrigações patrimoniais, nem mesmo com a experiência recente de detenções ilegais e arbitrárias de um governo autoritário e ditatorial (1964-1982); manteve no texto constitucional a possibilidade de prisão por dívida civil (artigo $5^{\circ}$ LXVII) - na prática cotidiana dos Tribunais lida como alternativa para a cobrança ao alimentante renitente. 
A jurisprudência tem se manifestado no sentido de superação da tendência punitiva para a construção de alternativas, sem fazer uso da prisão civil, para ver compelido o alimentante faltoso ao cumprimento da obrigação. A multa, conhecida como astreinte, tem se apresentado como eficaz. Quando, porém, pontuados os direitos à dignidade da pessoa humana (vida) e à liberdade, necessário se faz um passo a mais. Neste sentido, a vanguarda coloca-se nas decisões do Parlamento Europeu ao estabelecer o Fundo de Garantia dos Alimentos Devidos a Menores, sob responsabilidade do Estado, mas com capacidade para sub-rogar-se no direito de cobrar do devedor alimentante moroso. Protege-se, desta forma, o direito à vida e o direito à liberdade. Cumpre-se, então, o dever de cuidado, responsabilidade do genitor, com a intervenção do Estado.

Conclui-se destacando que o senso comum no Direito brasileiro ainda é o de utilizar o judiciário como instrumento para cobrar direitos obrigacionais ou patrimoniais, como era visível nas ações falimentares, grande parte delas utilizadas tão somente para compelir o devedor empresário ao pagamento de títulos executivos, vício rompido com a promulgação da lei n. 11.101 de 9 de fevereiro de 2005.

Este mesmo avanço é necessário em relação à prisão civil por dívida. Uma (re)leitura das Convenções e Tratados Internacionais e dos Princípios positivados na Constituição Brasileira de 1988, torna imperativo superar a visão tradicional de criminalizar e punir, ao invés de construir uma cultura de participação e cuidado. É o que se propõe.

\section{REFERÊNCIAS}

ANDORNO, Roberto. Bioética y dignidad de la persona. 2. ed. Madrid: Tecnos, 2012.

ASSIS, Araken de. Manual da execução. 11. ed. São Paulo: RT, 2007. p. 905-906. 
BARROS, Sergio Resende de. Direitos Humanos da família: principiais e operacionais. Disponível em: <http://www.srbarros.com.br/pt/direitos-humanos-da-familia-principiais-e-operacionais.cont>. Acesso em: 2 mar. 2013.

BERGER, P.; LUCKMANN, T. A construção social da realidade. Petrópolis: Vozes, 1976.

BOBBIO, Norberto. A era dos Direitos. 1. ed. 12. tir. Rio de Janeiro: Campus, 1992.

CAHALI, Yussef Said. Dos alimentos. 6. ed. São Paulo: Revista dos Tribunais, 2009.

CANOTILHO, José Joaquim Gomes. Direito Constitucional e Teoria da Constituição. 3. ed. Coimbra: Almedina, 1998.

CORTE INTERAMERICANA DE DIREITOS HUMANOS. Caso Bámaca Velásquez. Sentença de 25.11.2000. São José da Costa Rica, 2001.

DIAS, Maria Berenice. Manual de Direito de família. 8. ed. São Paulo: RT, 2012.

DIDIER JUNIOR, Fredie et al. Curso de Direito Processual Civil. 4. ed. Salvador: Editora Juspodivm, 2012. p. 708-709. Vol. 5.

GOMES, Luiz Flávio; MAZZUOLI, Valerio de Oliveira. Comentários à Convenção Americana sobre Direitos Humanos. São Paulo: Revista dos Tribunais, 2009.

GOMES, Orlando. Direito de família. Rio de Janeiro: Forense, 1968.

GRISARD FILHO, Waldyr. O futuro da prisão civil do devedor de alimentos: caminhos e alternativas. Disponível em: <http://www.academia. edu/1435914/O_futuro_da_prisao_civil_do_devedor_de_alimentos_ caminhos_e_alternativas $>$. Acesso em: 11 mar. 2013.

JAYME, Fernando G. Direitos humanos e sua efetivação pela Corte Interamericana de Direitos Humanos. Belo Horizonte: Del Rey, 2005.

LINARD, Daniel Gurgel; ALCÂNTARA, Michele Alencar da Cruz. A influência do Pacto de San José da Costa Rica no Instituto da Prisão Civil do Depositário Infiel no Brasil. Trabalho publicado nos In: ENCONTRO NACIONAL DO 
CONPEDI, 19., 2020, Fortaleza. Anais... Fortaleza, CE, 9, 10, 11 e 12 jun. 2010. Disponível em: <http://www.conpedi.org.br/manaus/arquivos/anais/ fortaleza/3332.pdf $>$. Acesso em: 2 mar. 2013.

LOBO, Paulo. Direito de família e colisão de direitos fundamentais. Revista dos Tribunais, ano 101, v. 920, jun. 2012.

LUÑO, Antonio Enrique Pérez Luño. Derechos Humanos, Estado de Derecho y Constitución. 6. ed. Madrid: Tecnos, 1999.

MADALENO, Rolf. Direito de família - aspectos polêmicos. 2. ed. Porto Alegre: Livraria do Advogado, 1999.

MARMELSTEIN, George.Curso de direitos fundamentais. São Paulo: Atlas, 2009 .

MAZZUOLI, Valerio de Oliveira. Tratados Internacionais de Direitos Humanos e Direito Interno. São Paulo: Saraiva, 2010.

MIRANDA, Francisco Cavalcanti Pontes de. Tratado de direito privado. 4. ed. São Paulo: RT, 1983. T. 9, §1.000, n. 1.

MONTEIRO, Marco Antonio Corrêa. Tratados internacionais de Direitos Humanos e Direito Interno. São Paulo: Saraiva, 2011.

PORTUGAL. Decreto-Lei nº 164/99. DR nº 111/99 Série I-A de 1999-05-13, Ministérios da Justiça e do Trabalho e da Solidariedade. Regula a garantia de alimentos devidos a menores prevista na Lei n. ${ }^{\circ}$ 75/98, de 19 nov. 1998.

REVISTA Brasileira de Direito de Família, v. 5, n. 18, p. 124-126, jan./jun. 2003. SARLET, Ingo Wolfgang. A eficácia dos Direitos Fundamentais. 5. ed. Porto Alegre: Livraria do Advogado, 2005.p. 35-36.

SCOTTI, Luciana B. El reconocimiento extraterritorial de la "maternidad subrogada”: una realidad colmada de interrogantes sin respuestas jurídicas. Revista Pensar en Derecho, Buenos Aires, UBA, n. 1, 2012.

SUPREMO TRIBUNAL FEDERAL. HC 83.416-SP. Rel. Cezar Peluso, j. 14.10.2003. 
VENOSA, Sílvio de Salvo. Direito Civil. Direito de família. 10. ed. São Paulo: Atlas, 2010.

Sites consultados

$<\mathrm{http}: / / w w w . j u s p o d i v m . c o m . b r>$

$<$ http://www.sdh.gov.br>

$<$ http://www.senado.gov.br/>

$<\mathrm{http}: / /$ www4.seg-social.pt $>$

Recebido em: 15/4/2013

Revisado em: 27/8/2013

Aceito em: 9/10/2013 